Pak. j. sci. ind. res. Ser. A: phys. sci. 2020 63A(3) 162-167

\title{
Development and Characterization of Antibacterial Activated Carbon Composite of Zinc and Oxide for Water Filtration as an Industrial Application
}

\author{
Shahid Hussain Abro ${ }^{a *}$, Hazim Abdulaziz Moria ${ }^{b}$, Mohammad N. Alghamdi ${ }^{b}$, \\ Abdulaal Zuhayr Al-Khazaal ${ }^{b}$ and Syed Saad-Ul-Haque ${ }^{c}$ \\ a Department of Materials Engineering, NED University of Engineering \& Technology, \\ Karachi, Pakistan \\ ${ }^{b}$ Mechanical Engineering Technology Department, Yanbu Industrial College, KSA \\ ${ }^{\mathrm{c}}$ Chemical and Materials Engineering, Northern Border University Arar, KSA
}

(received August 8, 2019; revised September 3, 2019; accepted September 3, 2019)

\begin{abstract}
A scientific approach has been adopted in this research work to develop an antibacterial composite material by synthesizing the zinc and oxide together along with activated composite of carbon. $\mathrm{NH}_{3}, \mathrm{H}_{2} \mathrm{O}_{2}$, $\mathrm{ZnO}, \mathrm{AC}$ and $\mathrm{H}_{2} \mathrm{O}$ were used in this context. Embedded together to convert the zinc oxide to activated carbon. The $2.5 \mathrm{~g}$ of zinc oxide along with $45 \mathrm{~mL}$ of ammonia mixed with $4 \mathrm{~mL}$ of $\mathrm{H}_{2} \mathrm{O}_{2}$. After that $250 \mathrm{~g}$ of activated carbon along with precursor solution was soaked for a period of $3 \mathrm{~h}$. Immediately, after soaking the solution was kept for drying at room temperature for a period of $12 \mathrm{~h}$. After drying, the product was sintered in the sintering furnace at a temp: of $248^{\circ} \mathrm{K}\left(120^{\circ} \mathrm{C}\right)$ for a soaking period of $2 \mathrm{~h}$. The morphology was analyzed with the help of XRD and SEM. The XRD peaks clearly shows the zinc oxide and activated carbon product and also the SEM micrographs reveal the porous structure of the composite of $\mathrm{ZnO}$ activated carbon. It is concluded that the antibacterial activated carbon composite of zinc and oxide was successfully developed and can be used for water filtration.
\end{abstract}

Keywords: composite, activated carbon, zinc oxide, water filtration, XRD, SEM etc.

\section{Introduction}

The water pollution has been the major global issue in the past years. According to WHO (World Health Organization) impure water, less hygiene and sanitation are the main causes of death with estimate deaths of 871,000 in 2012 (WHO, 2015). These deaths have mostly been observed in lesser income societies and usually within the children age period of 5 years. Even around 6,600,000,000 people have been using better drinkable water sources according to the research of 2015 , but the coverage of those services to safely provide the drinking water has been quite low with an estimation of $67 \%$ metropolitan areas and $21 \%$ in pastoral regions. (Azizullah et al., 2011). It has been estimated that about $1 / 3$ of the inhabitants does not have the ingress to improved sanitation (free from germs) means around 946,000,000 population who performed open excretory products. (Sumrit et al., 2015; Zhang et al., 2011). It was estimated that 108 thousand deaths occurred due to involuntary poisoning. In the low middle income countries like Pakistan insecticides, kerosene, chemicals

*Author for correspondence; E-mail: engrabro@neduet.edu.pk for household and $\mathrm{CO}$ (carbon monoxide) are all one of the main causes of this unintentional poisoning. (Ali et al., 2017; Wisner et al., 2006). In developed countries the material involved for the poisoning contain $\mathrm{CO}$ (carbon monoxide), medicines and personal care items in the home. Therefore, the need for the water purification should be the top most priority for ensuring the safety of public drinking water. (Lu et al., 2015; Wiesner et al., 2006). Deployment of activated carbon (AC) in the filtration of water has been one of the keen interests of scientists and researchers because of its high surface area and its micro porous structure. (Shahid et al., 2019; Kumar, 2015). Activated carbon has been found greatly effective in removing the impurities in contaminated water. It is also known as an excellent absorbent for the nano or micro scale for the organic contaminants. But there is a limit for its use for the purification process. (Shahid et al., 2019; Ohira et al., 2016; Varaprasad et al., 2016). That is because the impurities which are adsorbed in activated carbon promote the fast growth of micro-organisms inside the activated carbon which results in secondary micro-organism contamination and reduces the life or activated carbon for water purification. 
(Cloudier et al., 2015; Bei, 2011; Stamenov et al., 2002). Some researchers have conducted that it is possible to impregnate the metallic particles into AC (activated carbon) which can be used to eliminate the microbes. Metals such as silver and zinc Nano particles have been found effective when used with activated carbon for bacteria elimination purposes. (Ali et al., 2018; Gaashani et al., 2013; Ali et al., 2012; Padmavathy and Vijayaraghavan, 2008; Ali and Gupta, 2006). The reason for the use of $\mathrm{ZnO}-\mathrm{AC}$ (zinc oxide activated carbon) in this project is because of the low cost and the ease of production which could result as a promising solution for the water purification problem in Pakistan. One of the drawbacks of activated carbon is a short service life this is due to the contaminants which can be filled in the adsorbing pores of activated carbon. (Osman and Mustafa, 2018; Menaka and Subiya, 2016; Zhiyuan et al., 2016). Similarly one of the drawbacks of $\mathrm{ZnO}$ is that its large amount in human body is hazardous. (Ghorbanifar et al., 2015). Therefore, we aspire to increase the service life of activated carbon and reduce the quantity of $\mathrm{ZnO}$ as possible with the highest service efficiency. (Alidad et al., 2019; Kyunghwan and Hwang, 2014). The antibacterial property of zinc oxide activated carbon is applied to determine the ability of material to work against the bacteria. This sample is specifically work against the $E$-coli bacteria which can be killed by the presence of $\mathrm{ZnO}$ which are rested into the pores of activated carbon. When E-coli contaminated water is passed through the $\mathrm{ZnO}-\mathrm{AC}$ then it will be trapped into the pores of activated carbon and can be killed by zinc oxide. (Bao et al., 2012; Aboul and Ali, 2011).

\section{Materials and Methods}

The chemicals and experimental materials that were employed for synthesizing in this research and

Table 1. List of chemicals used to develop the $\mathrm{ZnO}$ activated carbon composite

\begin{tabular}{llll}
\hline \hline Chemical name & Formula & Company name & $\begin{array}{l}\text { Concen- } \\
\text { tration }\end{array}$ \\
\hline Ammonia solution & $\mathrm{NH}_{3}$ & Merck, Germany & $40 \%$ \\
Hydrogen peroxide & $\mathrm{H}_{2} \mathrm{O}_{2}$ & Merck, Germany & $37 \%$ \\
Zinc oxide & $\mathrm{ZnO}$ & Industrial Grade & - \\
Activated carbon & $\mathrm{AC}$ & Industrial Grade & - \\
Deionized water & $\mathrm{H}_{2} \mathrm{O}$ & Industrial Grade & $100 \%$ \\
\hline \hline
\end{tabular}

experimental work were buy from the local market. The complete description has been shown in the Table 1.

The materials and chemicals mentioned in the Table 1 were collected and embedded together to convert the zinc oxide to activated carbon. The $2.5 \mathrm{~g}$ of zinc oxide along with $45 \mathrm{~mL}$ of ammonia mixed with $4 \mathrm{~mL}$ of $\mathrm{H}_{2} \mathrm{O}_{2}$. After that $250 \mathrm{~g}$ of activated carbon along with precursor solution was soaked for a period of three hours. Immediately, after soaking the solution was kept for drying at room temperature for a period of $12 \mathrm{~h}$. After drying, the product was sintered in the sintering furnace at a temp: of $248^{\circ} \mathrm{K}\left(120^{\circ} \mathrm{C}\right)$ for a soaking period of $120 \mathrm{~min}$. The whole process cycle can be visualized in Fig. 1.

In this method the impregnation of $\mathrm{ZnO}$ nano-particle can occur by dissolving zinc sulphate in distilled water. This solution can be made in an Erlenmeyer flask. Then hexa methylene tetra amine can be added to this solution and the $\mathrm{pH}$. can be maintain add hydro chloric acid $\mathrm{HCl}$ and sodium hydroxide $(\mathrm{NaOH})$. Then we add activated carbon to this solution which is followed by continuous stirring in a shaking incubator at $70{ }^{\circ} \mathrm{C}$ for $24 \mathrm{~h}$. After that it is filtered and dried at the temperature of $70{ }^{\circ} \mathrm{C}$ for $24 \mathrm{~h}$. The solution is shown in Fig. 2.

The antimicrobial property of $\mathrm{ZnO}-\mathrm{AC}$ can be determined by the following two methods.

Spread plate method. This is the method which is used to determine the bacteria in the culture or in the solution. It is an easier method to determine the quantity of Bacteria.

2.5g Zn0+45mL Ammoinia $+4 \mathrm{~mL}$ Hydrogen peroxide

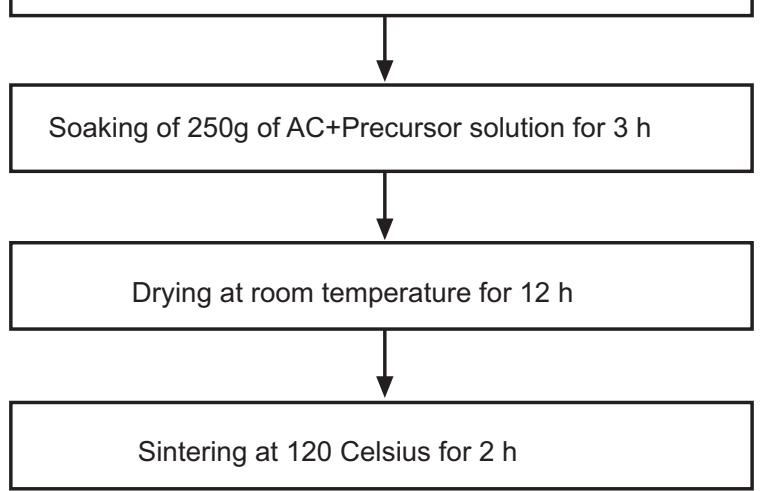

Fig. 1. Synthesize process flow chart of forming the solution. 
Principle of spread plate technique. In this method a sterile spreader is used having smooth surface made of metal or glass. A small amount of liquid can spread

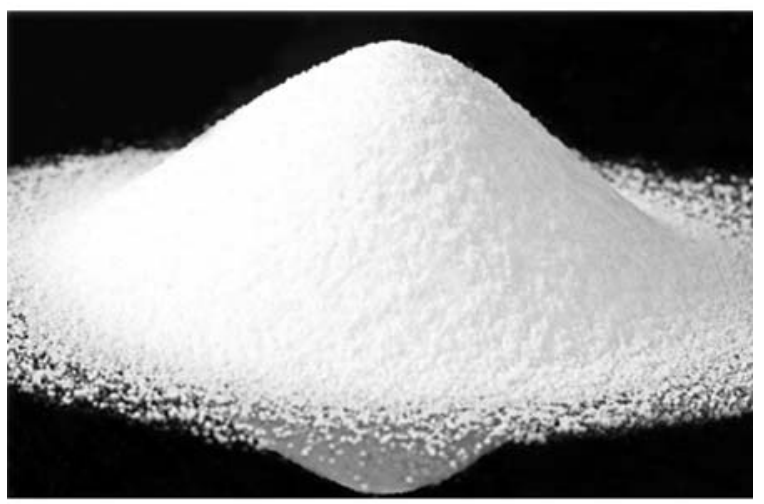

Powder of $\mathrm{ZnO}$

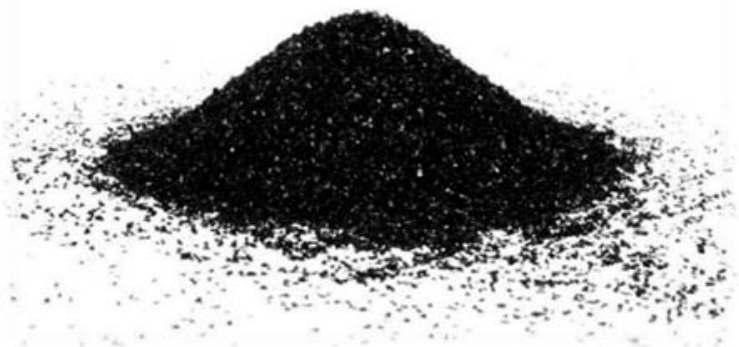

Powder of activated carbon.

Fig. 2. Powder of $\mathrm{ZnO}$, powder of activated carbon.

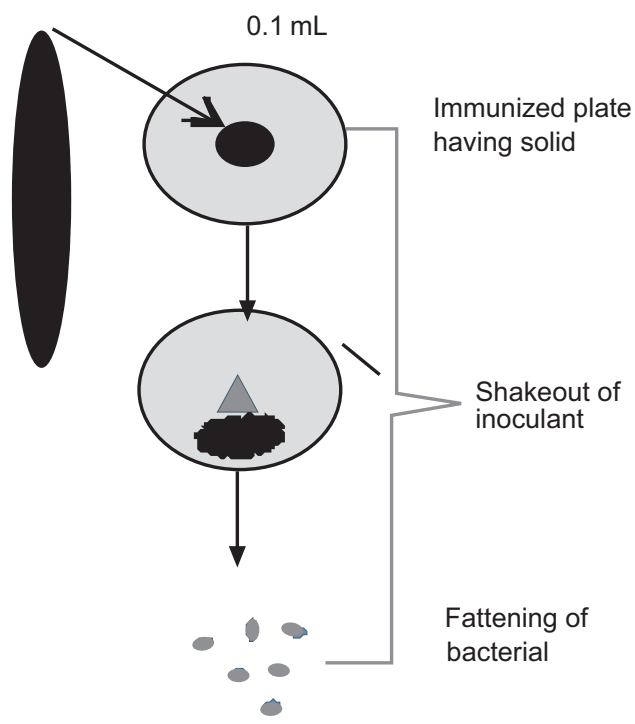

Fig. 3. Plate count technique. over the plate. Then this surface can be dry so that the agar can absorb the bacteria. A quantitative colonies of bacteria can be formed on the plate which can be distributed evenly.

The Fig. 3. indicates the bacteria development using the spread plate method. A liquid sample activated carbon composite was spread on the plate to distinguish and isolate the bacteria for easy counting in numbers the bacteria in solution. The visibility and randomly distributed colonies of bacteria are now easy countable. The quantity and score of isolated bacteria are shown also shown in table form in each XRD peaks results.

\section{Results and Discussions}

To confirm that $\mathrm{ZnO}$ and activated carbon were successfully developed, an XRD analysis was taken as shown in Fig. 4 and Fig. 5. The peaks in the Fig. 4 in which carbon has a high peak and score can confirms that it is the product of carbon known as activated carbon. The peaks in the Fig. 5 and the score shows that this material can contain a high percentage of zinc and oxygen which can make a compound of zinc oxide.

After individually development of $\mathrm{ZnO}$ and activated carbon and confirmed by the ERD peaks shown in Fig. 4 and 5, an antimicrobial zinc oxide-activated carbon composite was analyzed in the similar method by XRD machine. The peaks of the composite are shown in Fig. 6.

The Fig. 6 shows that the high percentage of carbon that confirms the activated carbon. The ammonia evolves from our product so it is beneficial for us having a small

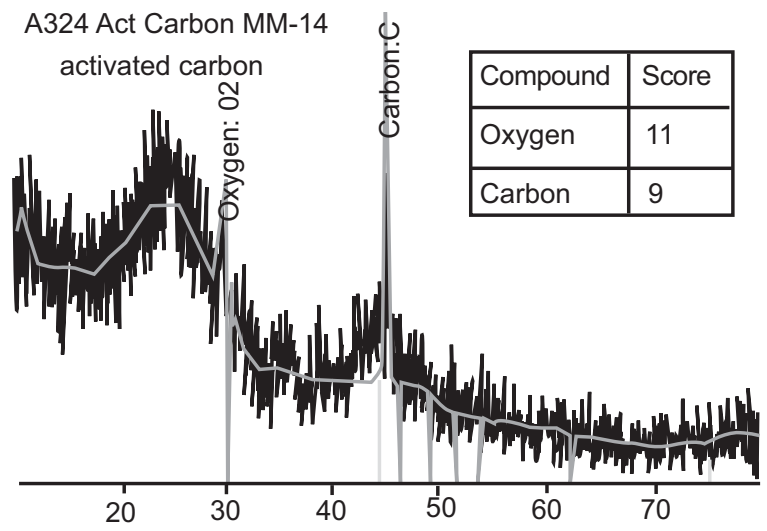

Fig. 4. Peaks of activated carbon indicates the presence of carbon. 
score. The product also contains high percentage of oxygen. But this time the zinc oxide is remain in the product and does not make any other compound with other species. So, we have some sufficient amount of zinc oxide.

This Fig. 7a indicates the presence of activated carbon because such a carbon can called activated carbon having high porosities in which a species can be rested. The Fig. 7b can show that it also contain $\mathrm{ZnO}$ which can rested in these pores and act against the E-coli Bacteria to remove it from water.

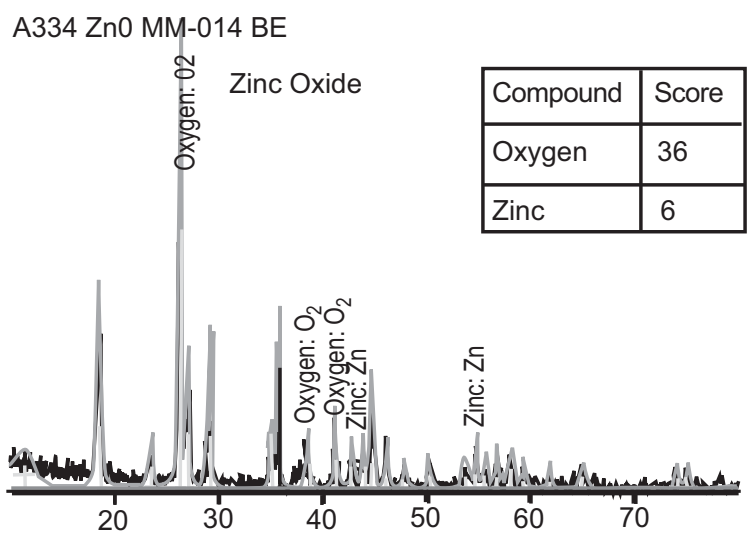

Fig. 5. Peaks of $\mathrm{ZnO}$ indicates the presence of zinc oxide.

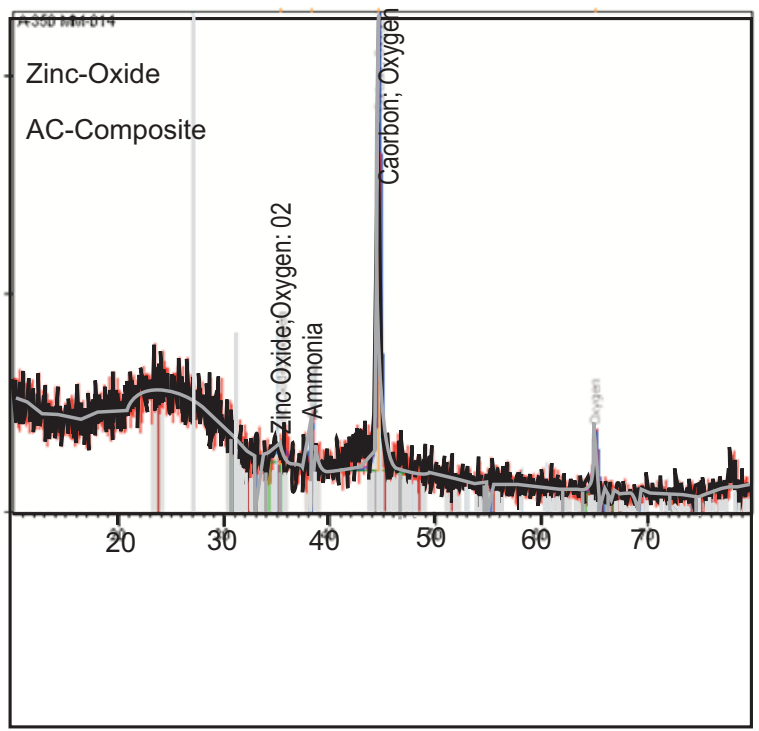

Fig. 6. XRD peaks shows the antimicrobial zinc oxide-activated carbon composite
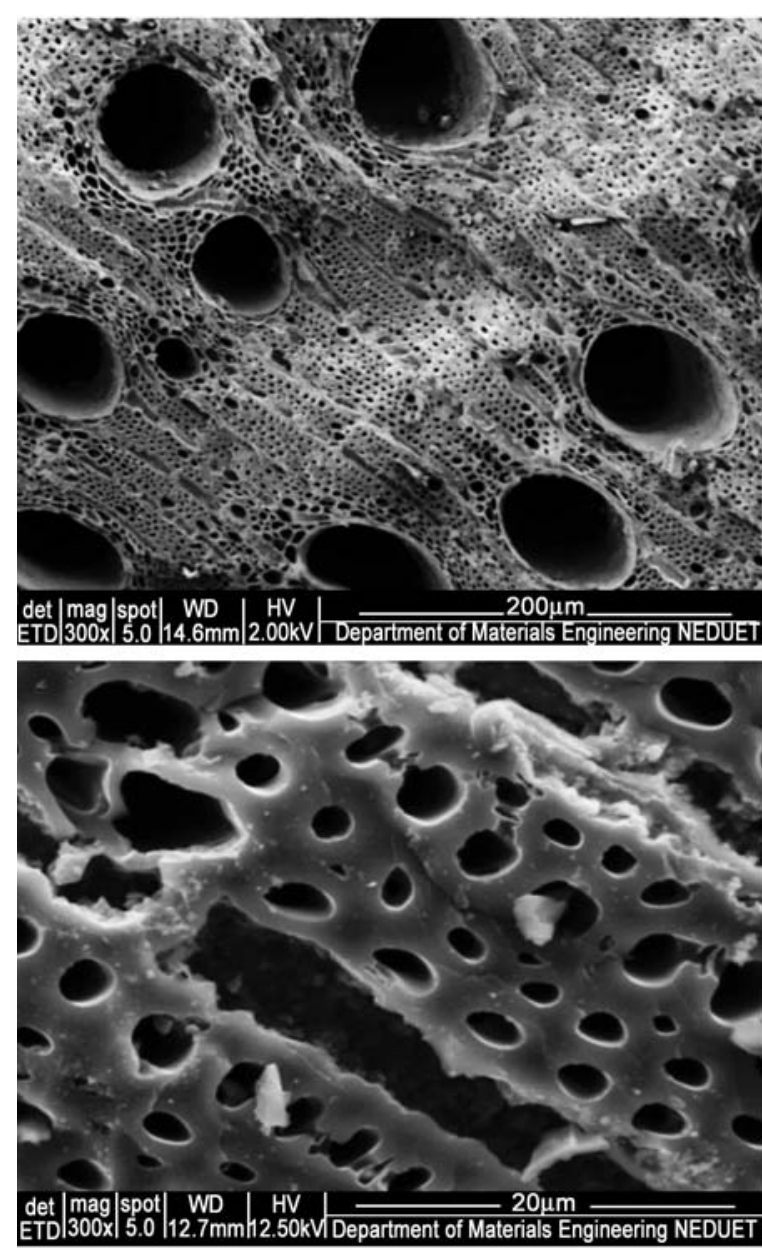

Fig. 7. SEM micrographs of $\mathrm{ZnO}$ and activated carbon composite.

\section{Conclusion}

In this research work it was successfully synthesis activated carbon and zinc oxide composite. The conformity of successfully synthesizing this composite product was done by the tools used for characterization such as X-ray diffraction (XRD) in addition of Scanning Electron Microscope (SEM). Three samples was developed and prepared in which sample " 3 " was the best one because the traces of $\mathrm{ZnO}$ were found in XRD pattern and have a peak around $35^{\circ}$. Moreover, $\mathrm{ZnO}$ have a score of "14" which confirms the traces of zinc oxide. Scanning Electron Microscope (SEM) images also provided confirmation for the presence of $\mathrm{ZnO}$ and formation of $\mathrm{ZnO}-\mathrm{AC}$ composite.

Future work. It is recommended and suggested to develop or culture the $E$-coli bacterial and a water filter. Water which is to be tested may be passed through this 
filter and then check the bacteria killed, minimized or eliminated completely.

\section{Acknowledgement}

Authors of this work are grateful to the department of Materials Engineering at NED University of Engineering and Technology and Yanbu Industrial College, for their valuable support to provide the laboratory facilities and the PCSIR Laboratories Karachi for providing the information and knowledge about this project.

Conflict of Interest. The authors declare no conflict of interest.

\section{References}

Ali, M., About-Enein, H.Y., Gupta, V.K., Aboul, E., Ali, I. 2011. Nano Chromatography and Capillary Electrophoresis: Pharmaceutical and Environmental Analyses, Wiley, ISBN: 978-0-470-17851-5.

Ali, I., Gupta, V. 2006. Advances in water treatment by adsorption technology, Nature. Protocol. 6: 26612667.

Ali, I. 2012. New generation adsorbents for water treatment, Chemical Review, 112: 5073-5091.

Ali, I., Asim, M., Khan, T.A. 2018. Low cost adsorbents for the removal of organic pollutants from wastewater, Journal of Environmental Management. 113: 170-183.

Al Gaashani, R., Radiman, S., Daud, A.R. 2013. XPS and optical studies of different morphologies of $\mathrm{ZnO}$ nanostructures prepared by microwave methods, Ceramical International, 39: 2283-2292.

Alidad, C., Shahid, H.A. 2017. Effect of temperature and time on nickel aluminide deposition, mechanical properties of AISI 4340 steel, Mehran University Research Journal of Engineering \& Technology, 37: 491-496.

Alidad, C., Basit, A., Shahid, H.A. 2019. Silicon carbide effect as reinforcement on aluminum metal matrix composite. Journal of Chemical Society of Pakistan, 41: 46-54.

Azizullah, M., Khattak, N.K., Haider, D.P. 2011. Water pollution in Pakistan and its impact on public health, Journal of Environmental International, 37: 479497.

Bao, L.J., Mariyah, K.A., Snyder, S.A., Zeng, E.Y. 2012. China's water pollution by persistent organic pollutants, Environmental Pollution. 163: 100-108.
Bei, E., Shu, Y., Li, S., Liao, X., Wang, J., Zhang, X., Chen, C., Krasner, S. 2011. Occurrence of nitrosamines and E.PA. water treatment manual: disinfection. Wexford, Ireland: Environmental Protection Agency; 36: 456-460.

Cloutier, M., Mantovani, D., Rosei, F. 2015. Antibacterial coatings: challenges, perspectives and opportunities. Trends Biotechnology, 33: 637-652.

Ghorbanifar, H.R., Mehr, F.P., Pazoki, H., Rahman, B.M. 2015. Synthesis of $\mathrm{ZnO}$ particles by precipitation method. Orient Journal of Chemistry, 31: 1219-1221.

Kumar, T.K.M.P. 2015. Highly efficient performance of activated carbon impregnated with $\mathrm{Ag}, \mathrm{ZnO}$ and $\mathrm{Ag} / \mathrm{ZnO}$ nanoparticles as antimicrobial materials, RSC Advances, 5: 108034-108043.

Kyunghwan, K., Hwang, G.B. 2014. Development and evaluation of antimicrobial activated carbon fiber filters using Sephora flavescent nanoparticles, Science of the Total Environment, 493: 291-297.

Lu, Y.L., Song,S., Wang, R.S., Liu, Z.Y., Meng, J., Sweetman, A.J., Jenkins, A., Ferrier, R.C., Li, H., Luo, W., Wang, T.Y. 2015. Impacts of soil and water pollution on food safety and health risks in China, Environment International, 77: 5-15.

Menaka, R., Subiya, R. 2016. Synthesis of zinc oxide nano powder and its characterization using XRD, SEM and antibacterial activity against Staphylococcus aureus. International Journal of Scientific Research, 5: 269-271.

Osman, D.A.M., Mustafa, M.A. 2018. Synthesis and characterization of zinc oxide nanoparticles using zinc acetate dehydrate and sodium hydroxide. Journal of Nano Science Nano Engineering, 1: 248-251.

Padmavathy, N., Vijayaraghavan, R. 2008. Enhanced bioactivity of $\mathrm{ZnO}$ nanoparticles an antimicrobial study. Science Technology Advanced Materials, 9: 235-240.

Shahid, H. A. 2019. On the effect of global warming and role of automotive industry. Pakistan Journal of Scientific and Industrial Research, 62: 179-201.

Shahid, H.A., Abdulaziz, S., Alaboodi, Iftikhar, A.C. 2019. Design, development and characterization of graphene sand nano-composite for water filtration. Pakistan Journal of Scientific and Industrial Research, 63: 118-122.

Sumrit, M., Pornsawan, A. 2015. Microporous activated 
carbon fibre from pineapple leaf fibre by $\mathrm{H}_{3} \mathrm{PO}_{4}$ activation. Asian Journal of Scientific Research, 9: $24-33$

Tayeong, O., Yamamoto. 2016, Antibacterial activity of $\mathrm{ZnO}$ powder with crystallographic orientation, Journal of Material Science and Materials Medicne, 19: 1407-1412.

Varaprasad, K., Raghavendra, G.M., Jayaramudu, T., Seo, J. 2016. Nano zinc oxide-sodium alginate antibacterial cellulose fibres. Carbohydras Polymer, 135: 349-355.

WHO, 2015. UNCS Fund. Progress on Sanitation and Drinking Water: Update and MDG Assessment pp, 233-238. Geneva, Switzerland.
Wiesner, M.R., Lowry, G.V., Alvarez, P., Dionysiou, D., Biswas, P. 2006. Assessing the risks of manufactured nanomaterials. Environmental Science and Technology, 40: 4336-4345.

Zhang, C.B., Xie, L.Z.F. 2011. Study on the antimicrobial properties of $\mathrm{ZnO}$ suspension against gram-positive and gram-negative bacteria strains. Advanced Materials Research, 5: 1488-1491.

Zhiyuan, L., Shuili, Y., Heedeung, P., Qingbin, Y. 2016. Impact of titanium dioxide nanoparticles on the bacterial communities of biological activated carbon filter intended for drinking water treatment, Environmental Science of Pollution Research, 23: 1557415583. 